\title{
Risk Mitigation Strategies in Implementing Scrum Framework for Internet-Based IT Companies in Indonesia
}

\author{
F S Rahayu*1, T Indrawan', S Kamarudin ${ }^{3}$ \\ ${ }^{1}$ Faculty of Industrial Technology, Universitas Atma Jaya Yogyakarta, Indonesia \\ ${ }^{2}$ Universitas Atma Jaya Yogyakarta, Indonesia \\ ${ }^{3}$ Faculty of Humanities, Management and Science, Universiti Putra Malaysia Bintulu \\ Sarawak Campus, Nyabau Road, PO Box 396, 97008 Bintulu, Sarawak, Malaysia
}

E-mail: saptyrahayu@gmail.com¹, toniindrawan96@gmail.com², shafinah@upm.edu.my ${ }^{3}$

Submitted: 19 August 2020, revised: 21 August 2020, accepted: 23 August 2020

\begin{abstract}
Abstrak. Sampai saat ini banyak Perusahaan Teknologi Informasi di Indonesia yang menerapkan Scrum Framework. Scrum Framework merupakan salah satu framework yang menggunakan prinsip Agile. Implementasi Scrum Framework tidak menjamin bahwa perusahaan-perusahaan tersebut bebas dari resiko, karena banyak resiko juga akan muncul selama implementasi framework itu sendiri. Oleh karena itu, diperlukan strategi manajemen risiko untuk memitigasi risiko tersebut. Penelitian ini merupakan penelitian kualitatif untuk mengelola risiko akibat penerapan Scrum Framework dalam pengembangan perangkat lunak perusahaan IT khususnya di Indonesia. Wawancara telah dilakukan kepada pemangku kepentingan scrum di tiga perusahaan IT untuk mengumpulkan beberapa data awal. Data tersebut kemudian lebih lanjut menggunakan metode Qualitative Content Analysis dan Risk Breakdown Structure. Temuan kami menunjukkan bahwa terdapat 17 Risk Register dan Strategi Mitigasinya untuk implementasi Scrum Framework di perusahaan IT Indonesia. Selain itu, ini dapat digunakan sebagai pedoman untuk pengambilan keputusan tentang apakah akan menerapkan kerangka kerja ini dalam bisnis utama mereka.
\end{abstract}

Kata kunci: Scrum framework; manajemen risiko; identifikasi risiko; agile principles, perusahaan IT

\begin{abstract}
To date many Information Technology Companies in Indonesia implement Scrum Framework which is one of the frameworks that uses Agile principles. The implementation of the Scrum Framework does not guarantee that these companies will be free from risk, since many risks will also appear during the implementation of the framework itself. Therefore, risk management strategies are needed to mitigate these risks. This research is a qualitative research to manage risk due to the implementation of Scrum Framework in software development of IT companies, especially in Indonesia. Interviews have been conducted to the Scrum stakeholders in three IT Companies to gather some initial data to be analyzed further using Qualitative
\end{abstract}


Content Analysis Method and Risk Breakdown Structure. Our finding shows that there are 17 Risk Registers and their Mitigation Strategies for the implementation of Scrum Framework in Indonesian IT Companies. Furthermore, it can be used as guidelines for decision making about whether to implement this framework in their core businesses.

Keywords: scrum framework; risk management; risk identification; agile principles, IT companies

\section{Introduction}

Risk is the conditions or events in the future that may occurs beyond the control of the project team that can potentially be harmful to the project [1]. Risks should be properly mitigated because the occurrence of these risks will cause failure to the project, such as inability to fulfill user's request and expectations, to meet the desired time schedule, or to meet the expected budget. To manage these risks, project team must implement some risk management strategies. Cooper et.al defines risk management is the culture, process, and structure to effectively manage the potential occurrence of harmful events [2]. The global survey of Financial Service Risk Management conducted biannually showed that only $60 \%$ of the respondents are applying risk management in their companies, whereas the remaining $40 \%$ are not implementing any risk management strategies at all [3]. It can be seen from the study that there is a lack of awareness of the importance of risk management in many companies.

Risk management strategies in Information Technology (IT) Companies are usually applied to their Software Development Life Cycle (SDLC) phases. SDLC is a list of phases needs to be conducted when building software which is usually includes planning, analyzing, designing, and implementing the software [4]. In some conventional SDLCs such as Waterfall, Spiral, or V-model, the phases are conducted sequentially so that the implementation of conventional risk management strategies is easier. However, these conventional SDLCs are no longer used by many IT Companies due to its inability to cope with the ever-increasing software complexity and user's demands. The new types of SDLC are emerging and one of them is Scrum Framework which is an implementation of Agile Principles.

Scrum Framework is a framework that enables people to cope with complex adaptive problems, while productively and creatively making products with highest possible values [5]. Scrum Framework is adaptive since it enables team to be ready to accommodate changing requirements at any time [6]. In State of Agile Survey, it is shown that 52\% of organizations using Scrum Framework as the framework to develop software [7]. The adoption of the Scrum Framework also has several risks. However, the study of risk mitigation strategies of software development using scrum is low [8] [9]. The previous studies show that they use a Systematic Literature Review (SLR) to identify the risks and related strategies [10].

However, there is a gap between the SLR model and real-life observation. For this reason, some IT Companies in Indonesia adopt Scrum Framework to develop their software and the numbers are continuously increasing despite the risks of Scrum implementation. To address this condition, the study of Risk Mitigation Strategies in a real situation are needed. Shortly, our study is to explore and accommodate these companies when they are using the Scrum framework.

\section{Current Studies}

There are several studies relating the risk management in non-IT-related and IT-related companies and more specifically in Indonesia. One of the study shows that incorrect selection of the SDLC is also corresponds to the risk, even though Waterfall Model is the mostly used SLDC [4]. The Waterfall Model has several weaknesses such as the problem arise in one phase cannot be completely mitigated in the next phase of development; secondly the client cannot change the requirements; thirdly the rigid scope the contract requirement [4]. The other study states that $70 \%$ of the software projects using this Waterfall Model are failing to determine one or more goal of the project [6]. Whereas in Indonesia, there is the study of risk management process in data processing unit at PT. Petrokimia Gresik [11]. 
The solution to overcome the shortcomings of the conventional SDLC's such as Waterfall Model is applying Scrum Framework which is one of the implementation of Agile Principles. Scrum Framework is used in implementation related to public relation [12]. Other Agile Principles approach is Distributed Agile Development (DAD) for software development that able to identify five risk categories such as SDLC's risk factors, project management risk factors, team awareness risk factors, external stakeholder collaboration risk factors, and technology arrangement risk factors [13] which should be responded.

Risk response planning is a process to develop several strategies to increase opportunities and decrease threats to the project [14]. The strategies include risk avoidance, risk transfer, risk acceptance, risk monitoring, risk mitigation, and developing contigency plan and strategic plan[15].Moreover, these risks could be related to several responses [16][17]. Since not all risks can be eliminated, the risk mitigation and its optimation sometimes are the best approaches[18]. This mitigation, viewed as more effective solutions than damage repairment [14][19], and other backup plan are developed to decrease the impact of the risk.

Based on the current conditions which are (1) IT project management is a relatively new area and (2) Scrum Framework is relatively new methodology, so in developing countries such as Indonesia this research areas have limited publications. This paper attempts to fill the gap by identifying risks that might happen and developing mitigation strategies for these risks [20][21][22][23][24]. The findings will be useful as the guidelines for IT Companies especially in Indonesia which are already using or planning to use Scrum Framework in their product development.

\section{Research Methodology}

This research is a qualitative research in which the purpose is to generate risk mitigation strategies in implementing Scrum Framework during software development based on the perspective of Scrum's stakeholder. The research methodology is conducted in the following phases:

1) Determine the companies as the subject of the research using Purposive Sampling Method [25].

2) Gather risk information using semi-structured interviews [13], which divided into three components: Identity of the interviewees, interview and then Follow up based on Theory Driven [26].

3) Validate data using data triangulation [25] and member checking [27].

4) Analyze data using Qualitative Content Analysis Method [27].

The unit here is the transcript of the interview and the codes are phrases or sentences from the transcript. The subcategories are the risk identified from the codes, and the categories are the groupings of the risks based on the Risk Breakdown Structure from The Project Management Body of Knowledge [14] as shown in Figure 1 below.

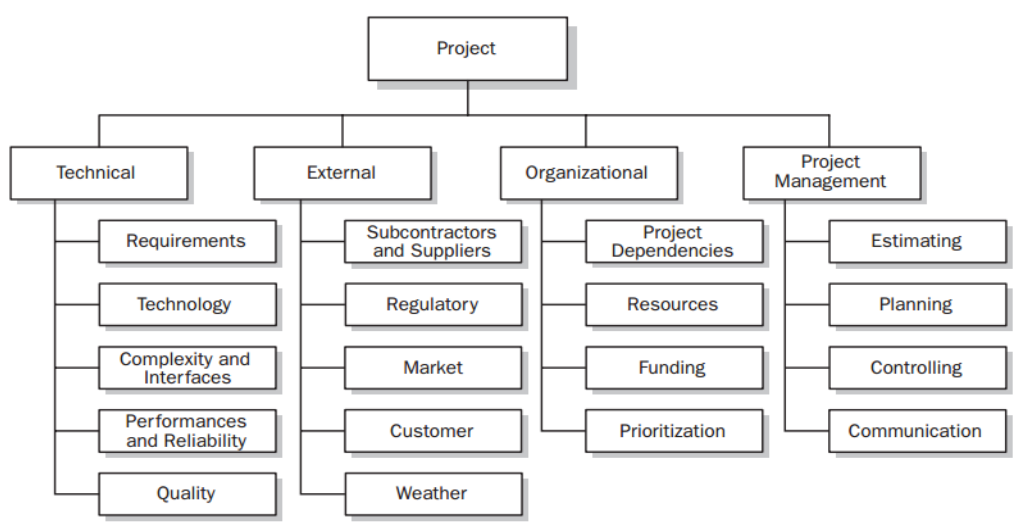

Figure 1. Risk Breakdown Structure [14] 
Each of the risk is analyzed further by identifying the description, cause, and impact of the risks in the form of Risk Register [28]. This list can be used as guidelines for IT Companies which is considering in implementing Scrum Framework in their core business. Determine the risk probability and risk impact categories based on the description of each cause and impact in the risk register. The combination of the risk probability and risk impact will determine the risk exposure. The risk exposure also determines the priority of the risk. Finally, the risk mitigation strategies are suggested for managing these risks.

\section{Result and Analysis}

The selection of the IT companies using Purposive Sampling [25] and it is performed by criteria, that company should be Indonesian IT companies which already implemented Scrum Framework for at least one year. There are three companies selected as the subject of research which are:

1) $A B C$ is a news portal which collects news from many online media by implementing machine learning and recommendation system. The $\mathrm{ABC}$ app has been downloaded more than $40 \mathrm{~K}$ times in Google Play and rated 3.4 stars with 36th rank in News in App Store in 2018.

2) $X Y Z$ is one of five startup unicorns in Indonesia which has value more than $\$ 1$ billion. It is a $\mathrm{C}$ to-C e-commerce platform that is very popular in Indonesia. XYZ app has been downloaded more than 10 million times in Google Play and rated 4.8 stars with 2nd rank in Shopping in App Store in 2018.

3) $E F G$ is a grocery delivery app in which users can order groceries from popular grocery stores and delivered to the users' home at their convenient. EFG app has been downloaded more than 1 million times in Google Play and rated 4.4 stars with 10th rank in Food \& Drink in App Store in 2018.

The risk gathering is conducted by interviewing selected personels from these three IT companies. The interviews were conducted to 5 interviewees from $\mathrm{ABC}, 7$ interviewees from $\mathrm{XYZ}$, and 8 interviewees from EFG. The interviews are recorded and then transcripted for further analysis.The analysis using Qualitative Content Analysis [27] produces 17 identified risks of implementing Scrum Framework These 17 identified risks are then categorized based on the Risk Breakdown Structure as shown in Figure 1, and it is classified as shown in Table 1.

Table 1. Categorizing The Identified Risks

\begin{tabular}{lll}
\hline \multirow{2}{*}{ Risk Categories } & \multicolumn{1}{c}{ Identified Risk } \\
\cline { 2 - 3 } Technical & Risk ID & \multicolumn{1}{c}{ Risk Name } \\
\hline \multirow{3}{*}{ External } & R02 & Unclear requirements \\
& R03 & Unclear project goals. \\
& R04 & Incompatibility in pair programming. \\
& R05 & Very fast requirement changes. \\
& R06 & Existence of dependencies. \\
& R07 & Unoptimized work. \\
Organization & R08 & Ineffective numbers and compositions of team members. \\
& R09 & No specific product owner. \\
& R10 & Minimized role of QA in Scrum processes. \\
& R11 & Disruptive additional meetings. \\
& R12 & Misinterpretation of Agile Principles. \\
& R13 & Ineffective communication. \\
& R14 & Unprepared Sprint Planning. \\
Project Management & R15 & Ineffective Daily Scrum. \\
& R16 & Sprint Restrospective is not conducted routinely. \\
& R17 & Additional work in the middle of Sprint. \\
\hline
\end{tabular}


It can be observed from table 1 that there are some interesting findings about these identified risks :

1) Most of the risks are from organization category with 7 risks, followed by project management category with 5 risks, technical category with 4 risks, and external category with only one risk.

2) Most of the identified risks in organization category are related to the discipline in implementing the Scrum Framework practices.

3) Most of the identified risks in project management category are related to the effectiveness of the Scrum Framework practices.

4) Most of the identified risks in technical category are related to clarity of the goals and the discipline in creating documentation.

5) The only identified risk in external category, which is very fast requirement changes, is actually the reason that Scrum Framework should be used in the first place. Every Internet-based IT companies will face the similar challenges.

Each of the identified risks is then analyzed further in forms of description, cause, and impact and then tabulated in the form of Risk Register [28]. Table 2, 3, 4, and 5 shows the Risk Register of each identified risk that categorized as Technical Risk.

Table 2. Risk Register of Unclear Requirements

\begin{tabular}{|c|c|}
\hline Risk ID & R01 \\
\hline Risk Name & Unclear requirements. \\
\hline Risk & Technical \\
\hline \multicolumn{2}{|l|}{ Category } \\
\hline Description & $\begin{array}{l}\text { There are unclear requirements according to the developers or stakeholders that make } \\
\text { them unable to produce the expected products. }\end{array}$ \\
\hline Category & Technical \\
\hline Cause & $\begin{array}{l}\text { - Developers are not knowing the overall requirements of the project and only given } \\
\text { requirements for each Sprint. } \\
\text { - Requirements are given in the form of stories that may be lacking in details. }\end{array}$ \\
\hline Impact & $\begin{array}{l}\text { - Developers cannot grasp the big picture of the product being developed. } \\
\text { - The work from the developers are not as expected by the project owner. } \\
\text { - Unclear acceptance criteria which will trigger bugs. }\end{array}$ \\
\hline
\end{tabular}

Table 3. Risk Register of Unclear Project Goals

$\begin{array}{ll}\text { Risk ID } & \text { R02 } \\ \text { Risk Name } & \text { Unclear project goals. } \\ \text { Risk Category } & \text { Technical } \\ \text { Description } & \text { The project goals are not properly understood by the developers, so that they have } \\ & \text { difficulty in predicting what to do to create product that fulfill the these goals. } \\ \text { Category } & \text { Technical } \\ \text { Cause } & \text { - Project Owner is giving project goals that are too general. } \\ & \text { - Project Owner is not able to describe the project goals clearly. } \\ \text { Impact } & \text { - Developers do not understand the goals of the project. } \\ & \text { - The work result from the developers is not as expected by the Project Owner. }\end{array}$

Table 4. Risk Register of lack of documentations

$\begin{array}{ll}\text { Risk ID } & \text { R03 } \\ \text { Risk Name } & \text { Lack of documentations. } \\ \text { Risk Category } & \text { Technical } \\ \text { Description } & \begin{array}{l}\text { The lack or absence of documentations about the product from both the developer } \\ \text { and management that will create several problems. }\end{array} \\ \text { Category } & \text { Technical } \\ \text { Cause } & \text { - Stakeholders are too lazy to produce documentations. }\end{array}$


- Developers feel that documenting is cumbersome task.

- Documentation is considered time wasting activity since changes in the product will also require changes in documentation.

Impact - Onboarding process of the new recruits will be longer.

- Difficulty in remembering created features when inquired by certain stakeholders.

- Quality Assurance (QA) personel will have difficulty to perform regression testing.

Table 5. Register of incompatibility in pair programming

\begin{tabular}{|c|c|}
\hline Risk ID & R04 \\
\hline Risk Name & Incompatibility in pair programming. \\
\hline Risk Category & Technical \\
\hline Description & $\begin{array}{l}\text { There are incompatibilities when performing pair programming with other } \\
\text { developer. These incompatibilities will make the developers cannot work } \\
\text { together in performing pair programming. }\end{array}$ \\
\hline Category & Technical \\
\hline Cause & The single-fighter character inside every programmer. \\
\hline Impact & The development process will slow down. \\
\hline
\end{tabular}

Table 6 shows the only identified risk that is categorized as External Risk, which is very fast requirement changes.

Table 6. Risk Register of very fast requirement changes

\begin{tabular}{ll}
\hline Risk ID & R05 \\
Risk Name & Very fast requirement changes. \\
Risk Category & External \\
Description & Requirement changes from market / users are so fast in which the company must \\
& $\begin{array}{l}\text { accommodate those changes in order to make its product competitive in the } \\
\text { market. }\end{array}$ \\
Category & External \\
Cause & - Agile organizations should be adaptive to changes. \\
& - Working in the Internet-based companies are challenging due to quick changes. \\
Impact & - Tasks that are marked done can be back as work in progress. \\
& - Inability to perform good development practices since everything must be done \\
& quickly.
\end{tabular}

Table 7, 8, 9, 10, 11, 12, and 13 shows the Risk Registers of the 6 identified risks categorized as Organization Risk.

Table 7. Risks Register for existence of dependencies

\begin{tabular}{ll}
\hline Risk ID & R06 \\
Risk Name & Existence of dependencies \\
Risk Category & Organization \\
Description & $\begin{array}{l}\text { The occurrence of dependencies in continuing work in the team scope as well as } \\
\text { the between-tasks scope that causes delays since one work must wait another } \\
\end{array}$ \\
$\begin{array}{l}\text { Work in order to be completed. } \\
\text { Category }\end{array}$ & $\begin{array}{l}\text { Organization } \\
\text { Cause }\end{array}$ \\
& Lack of details in planning (priority of the story is not considering the \\
& dependencies of codes
\end{tabular}


- Lack of communication and coordination among team members and the difference in priorities in the backlog works between the teams.

Impact Time of completion of one or more features will be longer.

Table 8. Register of unoptimized work

\begin{tabular}{ll}
\hline Risk ID & R07 \\
Risk Name & Unoptimized work. \\
Risk Category & Organization \\
Description & Developers cannot complete the work assigned to them due several reasons. \\
Category & Organization \\
Cause & - Scrum has tight completion time in each Sprint. \\
& - Developers will do their work in a hurry do the tight completion time. \\
& - Developers can get suffer illness / sickness. \\
Impact & - Scrum has tight completion time in each Sprint. \\
& - Developers will do their work in a hurry do the tight completion time. \\
& - Developers can get suffer illness / sickness.
\end{tabular}

Table 9. Risk Register of ineffective numbers and compositions of team members

Risk ID
Risk Name
Risk Category
Description

Category

Cause

Impact R08

Ineffective numbers and compositions of team members.

Organization

Ineffectiveness of the work due to the Scrum team conditions such as too many members or inaccurate composition of the team.

Organization

- The size of the team is different than what is recommended by Scrum Framework guidelines.

- The composition of the team members are not balanced between the senior and junior team members.

- Too many team members can create too many communication channels.

- Difficult to manage too many people at the same time.

- The junior team members have difficulty in adapting without the guidance from the senior members.

Table 10. Risk Register of no specific product owner

\begin{tabular}{ll}
\hline Risk ID & R09 \\
Risk Name & No specific product owner. \\
Risk Category & Organization \\
Description & $\begin{array}{l}\text { Nobody in the company who acts as specific Product Owner and work exclusively } \\
\text { as Product Owner. }\end{array}$ \\
Category & Organization \\
Cause & - The position of Product Owner is not yet assigned. \\
& - The title of Product Owner is given to specific managerial positions. \\
Impact & - Running out of Product Backlog (PB) since there is not time to create PB. \\
& - Product Owner rarely attends and follows the Scrum processes due to his / her \\
& activity in other managerial position. \\
& - Decrease in developer's morale.
\end{tabular}


Table 11. Risk Register of minimized role of QA in Scrum processes

\begin{tabular}{|c|c|}
\hline Risk ID & R10 \\
\hline Risk Name & Minimized role of QA in Scrum processes. \\
\hline Risk Category & Organization \\
\hline Description & $\begin{array}{l}\text { Quality Assurance personel who is one of the developer is never involved in } \\
\text { Scrum events such as Sprint Planning, Daily Scrum, Sprint Review, or Sprint } \\
\text { Retrospective. }\end{array}$ \\
\hline Category & Organization \\
\hline Cause & $\begin{array}{l}\text { - Lack of awareness from the development team that QA is important in the } \\
\text { Scrum Framework. } \\
\text { - QA personnel is involved only during testing of the features. }\end{array}$ \\
\hline Impact & Creating more bugs. \\
\hline
\end{tabular}

Table 12. Risk Register of disruptive additional meetings

$\begin{array}{ll}\text { Risk ID } & \text { R11 } \\ \text { Risk Name } & \text { Disruptive additional meetings. } \\ \text { Risk Category } & \text { Organization } \\ \text { Description } & \text { Additional meeting for developer which is not Scrum event that could disrupt } \\ & \text { developers in developing their work. } \\ \text { Category } & \text { Organization } \\ \text { Cause } & \text { - Request from the management. } \\ & \text { - Changes in meeting schedule. } \\ & \text { - Too many meetings. } \\ \text { Impact } & \text { - Disrupt the concentration of the developers during their work. } \\ & \text { - Disrupt the working time of the developers. } \\ & \text { - Disrupt the productivity of the developers. } \\ & \text { - Delay the completion of the current work. }\end{array}$

Table 13. Risk Register of misinterpretation of Agile Principles

\begin{tabular}{ll}
\hline Risk ID & R12 \\
Risk Name & Misinterpretation of Agile Principles. \\
Risk Category & Organization \\
Description & There are stakeholders who don't understand Agile Principles in Scrum \\
& Framework which makes the implementation of the framework ineffective. \\
Category & Organization \\
Cause & - Some stakeholders consider Scrum as mini Waterfall model. \\
& - Lack of interests from the developers about Scrum Framework and Agile \\
& Principles. \\
& - Developers are treated only as executor of the work / tasks / stories. \\
& - Developers are not fully understand the concepts of Agile Principles and Scrum \\
Impact & Framework. \\
& - Stakeholders want all the tasks during Sprint can be completed on time. \\
& There is no feeling of ownership to the product from the Scrum team.
\end{tabular}

Table 14, 15, 16, 17, and 18 shows the five identified risks categorized as Project Management Risk. 
Table 14. Risk Register of ineffective communication

\begin{tabular}{|c|c|}
\hline Risk ID & $\mathrm{R} 13$ \\
\hline Risk Name & Ineffective communication. \\
\hline Risk Category & Project Management \\
\hline Description & $\begin{array}{l}\text { Lack of effective communication due to human character aspects and } \\
\text { communication skills of each team members. }\end{array}$ \\
\hline Category & Project Management \\
\hline Cause & $\begin{array}{l}\text { - Some team members are introverts. } \\
\text { - Some characteristics of team members who are difficult to reach agreement. } \\
\text { - Limitation in English language skills. }\end{array}$ \\
\hline Impact & $\begin{array}{l}\text { - Uncomfortable working environment. } \\
\text { - Longer development process. } \\
\text { - Need for translator in communication in different languages. }\end{array}$ \\
\hline
\end{tabular}

Table 15. Risk Register of unprepared Sprint Planning

\begin{tabular}{|c|c|}
\hline Risk ID & R14 \\
\hline Risk Name & Unprepared Sprint Planning. \\
\hline Risk & Project Management \\
\hline Category & \\
\hline Description & The Scrum team makes incorrect decision during Sprint Planning. \\
\hline Category & Project Management. \\
\hline Cause & $\begin{array}{l}\text { - Over-estimation about the stories. } \\
\text { - Under-estimation about the stories. } \\
\text { - Lack of experience in Sprint Planning. }\end{array}$ \\
\hline Impact & $\begin{array}{l}\text { - Developers become unproductive if he / she finishes earlier than the estimated } \\
\text { time. } \\
\text { - Some tasks or stories are incomplete due to time limitation due to under- } \\
\text { estimation. }\end{array}$ \\
\hline
\end{tabular}

Table 16. Risk Register of ineffective Daily Scrum

\begin{tabular}{|c|c|}
\hline Risk ID & R15 \\
\hline Risk Name & Ineffective Daily Scrum \\
\hline $\begin{array}{l}\text { Risk } \\
\text { Category }\end{array}$ & Project Management \\
\hline Description & $\begin{array}{l}\text { The Daily Scrum process is not conducted properly that causes the member of Daily } \\
\text { Scrum unable to get benefit from participating in the Daily Scrum. }\end{array}$ \\
\hline Category & Project Management. \\
\hline Cause & $\begin{array}{l}\text { - Duration of daily Scrum is too long. } \\
\text { - Discussion of unnecessary technical issues during the Daily Scrum. } \\
\text { - Absence of Product Owner during Daily Scrum. }\end{array}$ \\
\hline Impact & $\begin{array}{l}\text { - Developers will be bored and not focused. } \\
\text { - Stakeholders who have no interest in technical issues will not having any benefits. } \\
\text { - Miscommunications will occur. }\end{array}$ \\
\hline
\end{tabular}


Table 17. Risk Register of Sprint Retrospectives is not conducted routinely

\begin{tabular}{ll}
\hline Risk ID & R16 \\
Risk Name & Sprint Restrospective is not conducted routinely. \\
Risk Category & Project Management \\
Description & Sprint Restropective, which is event in Scrum Framework to evaluate \\
& previous Sprint, is not conducted routinely. \\
Category & Project Management. \\
Cause & - No dedicated Scrum Master. \\
& - Sprint Restropective is considered waste of time. \\
Impact & - Difficulty in running the Scrum processes properly. \\
& - Developers have difficulty in expressing their troubles and any other \\
& matters without Sprint Restrospective. \\
& - No lesson-learned.
\end{tabular}

Table 18. Risk Register of additional work in the middle of Sprint

\begin{tabular}{ll}
\hline Risk ID & R17 \\
Risk Name & Additional work in the middle of Sprint. \\
Risk Category & Project Management \\
Description & $\begin{array}{l}\text { Additional work in forms of new stories or new tasks is added in the middle } \\
\text { of running Sprint. }\end{array}$ \\
Category & Project Management. \\
Cause & Additional work from management. \\
Impact & - Some stories must be postphoned to the next Sprint. \\
& - Developers must leave their current work to do higher priorities work.
\end{tabular}

These 17 Risk Registers shown in table 2 through table 18 shows the complete list of identified risks with all of the required analysis during Risk Identification phase of Risk Management. The next step of the study is determining the probability and impact of each risk in order to find the risk priority. The probability of the risk is determined by examining the causes of the risk from table II through table 18. Each cause is labeled and checked its correlation with other causes in the risk itself and other risk in order to determine its likelihood of occurrence that translates into the risk probability. The risk is then categorized into three probability category, ie. High, Medium and Low. The impacts of each risk are examined into three categories, which are:

1) $\mathrm{H}$ (High) : the impact may cause the incorrect or incomplete product.

2) M (Medium) : the impact may be fixed by the management, but some additional times will be required to perform the correction.

3) L (Low) : the impact may be fixed by the management in very short time.

The combination of risk probability and risk impact are the risk exposure which determines the priority of the risk. The top priority should be the $\mathrm{H}-\mathrm{H}$ exposure followed by decreasing exposure which are $\mathrm{M}-\mathrm{H}($ or $\mathrm{H}-\mathrm{M}), \mathrm{M}-\mathrm{M}$ (or $\mathrm{H}-\mathrm{L}$ or $\mathrm{L}-\mathrm{H}$ ), $\mathrm{M}-\mathrm{L}$ (or $\mathrm{L}-\mathrm{M}$ ), and then $\mathrm{L}-\mathrm{L}$ (the lowest exposure). Table 19 shows the complete list of the risk with probability, impact, exposure and the priority of the risk.

Table 19. Risk Priority

\begin{tabular}{llcccc}
\hline Risk ID & \multicolumn{1}{c}{ Risk Name } & P & I & RE & Priority \\
\hline R02 & Unclear project goals. & H & H & H - H & $\mathbf{1}$ \\
R01 & Unclear requirements & H & H & H - H & $\mathbf{2}$ \\
R03 & Lack of documentations. & M & H & M - H & $\mathbf{3}$ \\
R06 & Existence of dependencies. & H & M & H - M & $\mathbf{4}$ \\
R14 & Unprepared Sprint Planning. & M & M & M - M & $\mathbf{5}$
\end{tabular}




\begin{tabular}{|c|c|c|c|c|c|}
\hline Risk ID & Risk Name & $\mathbf{P}$ & $\mathbf{I}$ & $\mathbf{R E}$ & Priority \\
\hline R13 & Ineffective communication. & $\mathrm{M}$ & $\mathrm{M}$ & $\mathrm{M}-\mathrm{M}$ & 6 \\
\hline R17 & Additional work in the middle of & & & & \\
\hline & Sprint. & M & M & $\mathrm{M}-\mathrm{M}$ & 7 \\
\hline R05 & Very fast requirement changes. & M & M & $\mathrm{M}-\mathrm{M}$ & 8 \\
\hline R08 & $\begin{array}{l}\text { Ineffective numbers and } \\
\text { compositions of team members. }\end{array}$ & M & M & $M-M$ & 9 \\
\hline R16 & $\begin{array}{l}\text { Sprint Restrospective is not } \\
\text { conducted routinely. }\end{array}$ & $\mathrm{H}$ & $\mathrm{L}$ & $\mathrm{H}-\mathrm{L}$ & 10 \\
\hline $\mathrm{R} 10$ & $\begin{array}{l}\text { Minimized role of QA in Scrum } \\
\text { processes. }\end{array}$ & $\mathrm{L}$ & $\mathrm{H}$ & $\mathrm{L}-\mathrm{H}$ & 11 \\
\hline $\mathrm{R} 12$ & $\begin{array}{l}\text { Misinterpretation of Agile } \\
\text { Principles. }\end{array}$ & $\mathrm{L}$ & M & $\mathrm{L}-\mathrm{M}$ & 12 \\
\hline R11 & Disruptive additional meetings. & $\mathrm{L}$ & M & $\mathrm{L}-\mathrm{M}$ & 13 \\
\hline R15 & Ineffective Daily Scrum. & M & $\mathrm{L}$ & $\mathrm{M}-\mathrm{L}$ & 14 \\
\hline R09 & No specific product owner. & M & $\mathrm{L}$ & $\mathrm{M}-\mathrm{L}$ & 15 \\
\hline R04 & $\begin{array}{l}\text { Incompatibility in pair } \\
\text { programming. }\end{array}$ & $\mathrm{L}$ & M & $\mathrm{L}-\mathrm{M}$ & 16 \\
\hline R07 & Unoptimized work. & $\mathrm{L}$ & $\mathrm{L}$ & $\mathrm{L}-\mathrm{L}$ & 17 \\
\hline
\end{tabular}

It can be shown from Table 19 that most of the top priority risks are from technical and project management categories and most of the low priority risks are from organization category. IT Companies implementing Scrum Framework should pay more attentions in the technical and project management aspects in order to succeed. The risks that are in low priorities and categorized into organization and project management are related to the discipline in implementing Scrum Frameworks based on its guidelines and principles. Each of the risks, especially in the top priorities, should be mitigated by either reducing the probability or minimizing the impact or both. The mitigation strategies can be formulated and then executed in order to achieve the project's final goal. Table 20 shows the suggested risk mitigation strategies of the risk.

Table 20. Suggested Risk Mitigation Strategies

\begin{tabular}{cll}
\hline Risk ID & \multicolumn{1}{c}{ Risk Name } & \multicolumn{1}{c}{ Suggested Risk Mitigation } \\
\hline R02 & Unclear project goals. & Involving all stakeholders during brainstorming and planning \\
R01 & Unclear requirements & Having frequent meetings for all important stakeholders \\
R03 & Lack of documentations. & Hiring document specialist \\
R06 & $\begin{array}{l}\text { Existence of } \\
\text { dependencies. }\end{array}$ & Increasing modularity for every features developed during Sprint \\
R14 & $\begin{array}{l}\text { Unprepared Sprint } \\
\text { Planning. }\end{array}$ & Increasing knowledge and practices of Scrum Framework \\
R13 & $\begin{array}{l}\text { Ineffective } \\
\text { communication. }\end{array}$ & Having informal occasions to increase communications \\
R17 & $\begin{array}{l}\text { Additional work in the } \\
\text { middle of Sprint. }\end{array}$ & $\begin{array}{l}\text { Limiting additional task for developers currently assign into existing } \\
\text { project }\end{array}$ \\
R05 & $\begin{array}{l}\text { Very fast requirement } \\
\text { changes. }\end{array}$ & Increasing knowledge and practices of Scrum Framework \\
R08 & $\begin{array}{l}\text { Ineffective numbers and } \\
\text { compositions of team }\end{array}$ & Conducting effective and regular Sprint Restrospective \\
members. & Sprint Restrospective is \\
Rot conducted routinely. & Conducting effective and regular Sprint Restrospective \\
&
\end{tabular}

Rahayu, Indrawan, Kamarudin (Risk Mitigation Strategies in Implementing Scrum Framework for Internet-Based IT Companies in Indonesia) 


\begin{tabular}{cll}
\hline Risk ID & \multicolumn{1}{c}{ Risk Name } & \multicolumn{1}{c}{ Suggested Risk Mitigation } \\
\hline R10 & $\begin{array}{l}\text { Minimized role of QA in } \\
\text { Scrum processes. } \\
\text { R12 }\end{array}$ & $\begin{array}{l}\text { Involving QA during Daily Scrum and Sprint Restrospective } \\
\text { Agile Principles. }\end{array}$ \\
R11 & $\begin{array}{l}\text { Disruptive additional } \\
\text { meetings. }\end{array}$ & $\begin{array}{l}\text { Limiting additional task for developers currently assign into existing } \\
\text { project }\end{array}$ \\
R15 & $\begin{array}{l}\text { Ineffective Daily Scrum. } \\
\text { Increasing knowledge and practices of Scrum Framework }\end{array}$ \\
R09 & $\begin{array}{l}\text { No specific product } \\
\text { owner. }\end{array}$ & Assigning permanent Product Owner \\
R04 & $\begin{array}{l}\text { Incompatibility in pair } \\
\text { programming. }\end{array}$ & Having informal occasions to increase communications \\
R07 & Unoptimized work. & Having informal occasions to increase communications \\
\hline
\end{tabular}

Table 20 shows that some of suggested mitigations are similar which indicates that these strategies should be conducted and the result should accommodate the mitigation of more than one risks. The proper implementation of risk management when implementing Scrum Framework during software development will enable the IT Companies to properly anticipate most of the risks in order to increase the success of the development.

\section{Conclusion}

This research is able to formulate risk mitigation strategic related to the risks associated with the implementation of Scrum Framework when developing software in IT Companies especially in Indonesia. There are 17 identified risks based on the interviews to three selected Indonesian IT companies. These 17 identified risks are then categorized based on the Risk Breakdown Structure which are organization, technical, external, and project management. Each of the 17 identified risks are then tabulated into Risk Register that identify the additional information relating to the risk such as description, cause, and the impact of the risks. The risk probability and risk impact are determined in order to find the risk exposure and risk priority. The suggested risk mitigation strategies are proposed so that these findings could assist IT Companies wanting to success in implement Scrum Framework in their core businesses. Future work of the research is expanding the study by including more IT Companies in Indonesia, and also finding risk mitigation strategies in more specific types of IT Companies which result in more targeted risk mitigation strategies.

\section{References}

[1] Prasanta Kumar Dey, Jason Kinch, and Stephen O. Ogunlana, "Managing Risk in Software Development Projects: A Case Study," International Journal of Risk Assesment and Management, vol. 107, no. 2, pp. 284 - 303, 2007.

[2] Dale F. Cooper, Stephen Grey, and Geoffrey Raymond, Project Risk Management Guidelines: Managing Risk in Large Project and Complex Procurement. Chichester: John Wiley \& Sons Ltd, 2005.

[3] Deloitte. (2015, May) Deloitte Website. [Online]. http://www2.deloitte.com/global/en/pages/about-deloitte/articles/financial-services-riskmanagement-survey-press-release.html\#

[4] M. Mahalakshmi and DR. M. Sundararajan, "Traditional SDLC Vs Scrum Methodology - A Comparative Study," International Journal of Emerging Technology and Advanced Engineering, vol. 3, no. 6, pp. 192 - 196, 2013.

[5] Ken Schwaber and Jeff Sutherland. (2013, July) SCRUM GUIDES. [Online]. http://www.scrumguides.org/scrum-guide.html 
[6] Soumyadipta Paul and K. John Singh, "Be Agile: Project Development With Scrum Framework," Journal of Theoretical and Applied Information Technology, vol. 40, no. 1, pp. 105-112, 2012.

[7] Versionone, "State of Agile Survey," Atlanta, 2011.

[8] E., Babar, M. A., Paik, H. Y., \& Verner, J. Hossain, "Risk identification and mitigation processes for using scrum in global software development: A conceptual framework. ," 2009.

[9] I., Jabangwe, R., Šmite, D., \& Damian, D. Nurdiani,". Risk identification and risk mitigation instruments for global software development: Systematic review and survey results," 2011.

[10] S. Y., \& Idri, A. Chadli, "Identifying and mitigating risks of software project management in global software development," 2017.

[11] Aulia Febriayanti and Bekti Cahyo Hidayanto, "Manajemen Resiko Pada Pengelolaan Data di Bagian Pengelolaan Data PT. Petrokimi Gresik," Jurnal Teknik POMITS, vol. 1, no. 1, pp. 1 6, 2012.

[12] Betteke van Ruler, "Agile Public Relation Planning: Reflective Communication Scrum," Public Relations Review, vol. 41, no. 2, pp. 187 - 194, 2015.

[13] S.V. Shrivastava and U. Rathod, "Categorization of Risk Factors for Distributed Agile Projects," Information and Software Technology, vol. 58, no. 1, pp. 373 - 387, 2015.

[14] Project Management Institute, A Guide to The Project Management Body Of Knowlege, 4th ed. Pennsylvania: Project Management Institute, 2008.

[15] C. Ravindranath Pandian, Applied Software Risk Management: A Guide for Software Project Managers.: Auerbach Publications, 2006.

[16] R.F. Miorando, J.L.D Ribeiro, and M.N Cortimiglia, "An economic-probabilistic model for risk analysis in technological innovation projects," Technovation, vol. 8, no. 34, pp. 485 498, 2014.

[17] Y. Zhang, "Selecting risk response strategies considering project risk interdependence," International Journal of Project Management, vol. 5, no. 34, pp. 819 - 830, 2016.

[18] C. Fang, F. Marie, M. Xie, and E. Zio, "An Integrated Framework for Risk Response Planning Under Resource Constraints in Large Engineering Projects," IEEE Transactions on Engineering Management, vol. 3, no. 60, pp. 627 - 639, 2013.

[19] C Fang and F. Marie, "A Framework for the Modeling and Management of Project Risks and Risk Interactions," Handbook on Project Management and Scheduling, no. 2, pp. 1105 - 1117, 2014.

[20] J. Li et al., "A State-of-the-Practice Survey of Risk Management in Development with Offthe-Shelf Software Components," IEEE Transactions on Software Engineering, vol. 2, no. 34, pp. $271-286,2008$.

[21] E.T. Alharbi and M.R.J. Qureshi, "Implementation of Risk Management with SCRUM to Achieve CMMI Requirements," International Journal Computer Network and Information Security, no. 11, pp. 20 - 25, 2014.

[22] S.M. Neves and C.D.S. da Silva, "Risk management applied to software development projects in incubated technology-based companies: literature review, classification, and analysis," Gestao \& Producao, vol. 4, no. 23, 2016.

[23] B.G. Tavares, C.E.S da Silva, and A.D. Souza, "Risk Management in Scrum Projects: A Bibliometric Study," Journal of Communications Software and Systems, vol. 1, no. 13, 2017.

[24] S.V Shrivastava and U. Rathod, "A risk management framework for distributed agile projects," Information and Software Technology, no. 85, pp. 1 - 15, 2015.

[25] Robert K. Yin, Qualitative Research from Start to Finish, 1st ed. New York: A Division of Guilford Publication, Inc., 2011. 
[26] Uwe Flick, An Introduction to Qualitative Research, 4th ed. Reinbek bei Hamburg: SAGE, 2009.

[27] P. Burnard, P. Gill, K. Stewart, E. Treasure, and B. Chadwick, "Analysing and Presenting Qualitative Data," British Dental Journal, vol. 204, no. 8, 2008.

[28] Kathy Schwalbe, Information Technology Project Management. Boston: Course Technology, 2011.

[29] Iwan Iskandar, "Manajemen Risiko Teknologi Informasi Perusahaan Menggunakan Framework RiskIT (Studi Kasus: Pembobolan PT. Bank Permata, Tbk," Jurnal Sains, Teknologi dan Industri, vol. 9, no. 1, 2011.

[30] Martin Tomanek and Jan Juricek, "Project Risk Management Model Based on Prince2 and Scrum Framework," International Journal of Software Engineering \& Applications (IJSEA), vol. 6, no. 1, pp. 81 - 88, 2015.

[31] Robert Cecil Martin, Agile Software Development, 1st ed. Upper Saddle River: Alan R Apt, 2012.

[32] Joshua Partogi, Manajemen Modern dengan Scrum, 1st ed. Yogyakarta: ANDI, 2015.

[33] Youssef Bassil, "A Simulation Model for the Waterfall Software Development Life Cycle," International Journal of Engineering \& Technology (IJET), vol. 2, no. 5, 2012.

[34] R. Vijay Anand and M. Dinakaran, "Issues in Scrum Agile Development Principles and Practices in Software Development," Indian Journal of Science and Technology, vol. 8, no. 35, pp. 1-5, 2015.

[35] Yngve Lindsjorn, Dag I.K Sjoberg, Torgeir Dingsoyr, Gunnar R. Bergersen, and Tore Dyba, "Teamwork Quality and Project Success in Software Development: A Survey of Agile Development Teams," The Journal of Systems \& Software, 2016.

[36] Peggy Gregory, Leonor Barroca, Helen Sharp, Advait Deshpande, and Katie Taylor, "The Challenges That Challenge:Engaging With Agile Practitioner' Concerns," Information and Software Technology, 2016.

[37] the Agile Manifesto. (2001) Manifesto for Agile Software Development. [Online]. http://agilemanifesto.org/iso/id/manifesto.html

[38] Afshin Jalali Sohi, Marcel Hertogh, Marian Bosch Rekveldt, and Rianne Blom, "Does Lean \& Agile Project Management Help Coping With Project Complexity," , Panama, 2015. 